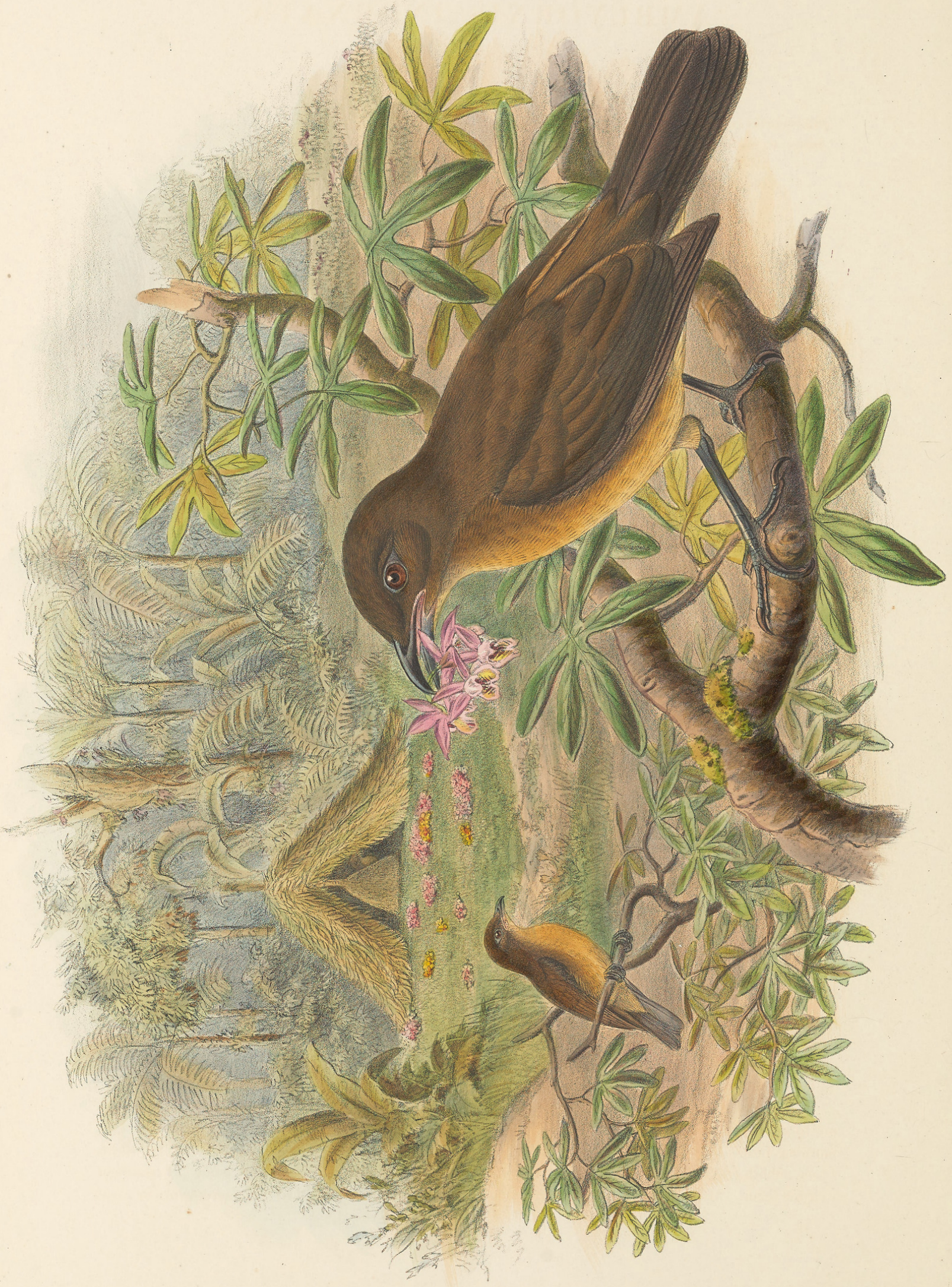

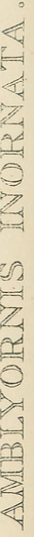




\title{
AMBLYORNIS INORNATA.
}

\author{
Gardener Bower-bird.
}

Ptilorhynchus inornatus, Schleg. Tijdsch. Dierk. vol. iv. p. 51 (1871).

Amblyornis inornata, Elliot, Ibis, 1872, p. 114.-Id. Monogr. Paradis. pl. xxxviii. (1873).-Sclater, P. Z.S. 1873, p. 697.-Salvad. Ann. Mus. Civ. Genov. vii. p. 780 (1875).-Id. op. cit. ix. p. 193 (1876-77).Beccari, tom. cit. p. 352, tav. viii.-Salvad. op. cit. x. p. 151 (1877).

IT was not until Baron Von Rosenberg penetrated into the interior of North-western New Guinea that the present species became known to science. It was first described by Professor Schlegel, who received specimens direct from the Baron, under the name of Ptilorhynchus inornatus. Shortly afterwards Mr. Elliot, when preparing his Monograph of the Paradiseidæ, pointed out that, in addition to the similarity of the sexes, the plumes which hide the nostril in Ptilorhynchus were wanting in the new species; and he therefore separated it under the name of Amblyornis.

The Malays call the bird "Gardener," from the floral decorations he gives to his bower and the lawn before it.

The following abstract of the article published by Dr. Beccari appeared in the 'Gardeners' Chronicle' for March 16th, 1878, from which I transcribe it :-

"The Amblyornis inornata, or, as I propose to name it, the Bird gardener, is a Bird of Paradise of the dimensions of a Turtledove. The specific name 'inornata' well suggests its very simple dress. It has none of the ornaments common to the members of its family, its feathers being of several shades of brown, and showing no sexual differences.

"It was shot some years ago by the hunters of Mynheer von Rosenberg. The first descriptions of its powers of building (the constructions were called 'nests') were given by the hunters of Mynheer Bruijn. They endeavoured to bring one of the nests to Ternate; but it was found impossible to do this, both by reason of its great size and the difficulty of transporting it.

"I have fortunately been able to examine these constructions at the remote places where they are erected. On June 20, 1875, I left Andai for Hatam, on Mount Arfak. I had been forced to stay a day at Warmendi to give rest to my porters. At this time only five men were with me; some were suffering from fever, and the remaining porters declined to proceed. We had been on our way since early morning; and at 1 o'clock we intended to proceed to the village of Hatam, the end of our journey.

"We were on a projecting spur of Mount Arfak. The virgin forest was very beautiful. Scarcely a ray of sunshine penetrated the branches. The ground was almost destitute of vegetation. A little track way proved that the inhabitants were at no great distance. A limpid fountain had evidently been frequented. I found here a new Balanophora, like a small orange or a small fungus. I was distracted by the songs and the screams of new birds; and every turn in the path showed me something new and surprising. I had just killed a small new marsupial (Phascologale dorsalis, Pet. and Doria) that balanced itself on the stem of a great tree like a squirrel; and turning round, I suddenly stood before the most remarkable specimen of the industry of an animal. It was a hut or bower close to a small meadow enamelled with flowers. The whole was on a diminutive scale. I immediately recognized the famous nests described by the hunters of Bruijn. I did not suspect, however, then that they had any thing to do with the constructions of the Chlamydoder $\mathscr{C}$. After well observing the whole, I gave strict orders to my hunters not to destroy the little building. That, however, was an unnecessary caution, since the Papuans take great care never to disturb these nests or bowers, even if they are in their way. The birds had evidently enjoyed the greatest quiet until we happened, unfortunately for them, to come near them. We had reached the height of about 4800 feet; and after half an hour's walk we were at our journey's end.

"The Nest.-I had now full employment in the preparation of my treasure; and I gave orders to my people not to shoot many of the birds. The nest I had seen first was the nearest one to my halting-place. One morning I took colours, brushes, pencils, and gun, and went to the spot. I there made the sketch which I now publish (fig. 56, p. 333). While I was there neither host nor hostess were at home. I could not wait for them. My hunters saw them entering and going out, when they watched their movements to shoot 
them. I could not ascertain whether this bower was occupied by one pair or by several pairs of birds, or whether the sexes were in equal or unequal numbers-whether the male alone was the builder, or whether the wife assisted in the construction. I believe, however, that such a nest lasts for several seasons.

"The Amblyornis selects a flat even place around the trunk of a small tree that is as thick and as high as a walking-stick of middle size. It begins by constructing at the base of the tree a kind of cone, chiefly of moss, of the size of a man's hand. The trunk of the tree becomes the central pillar; and the whole building is supported by it. On the top of the central pillar twigs are then methodically placed in a radiating manner, resting on the ground, leaving an aperture for the entrance. Thus is obtained a conical and very regular hut. When the work is complete many other branches are placed transversely in various ways, to make the whole quite firm and impermeable. A circular gallery is left between the walls and the central cone. The whole is nearly 3 feet in diameter. All the stems used by the Amblyornis are the thin stems of an orchid (Dendrobium), an epiphyte forming large tufts on the mossy branches of great trees, easily bent like straw, and generally about 20 inches long. The stalks had the leaves, which are small and straight, still fresh and living on them — which leads me to conclude that this plant was selected by the bird to prevent rotting and mould in the building, since it keeps alive for a long time, as is so often the case with epiphytical orchids.

"The refined sense of the bird is not satisfied with building a hut. It is wonderful to find that the bird has the same ideas as a man; that is to say, what pleases the one gratifies the other. The passion for flowers and gardens is a sign of good taste and refinement. I discovered, however, that the inhabitants of Arfak did not follow the example of the Amblyornis. Their houses are quite inaccessible from dirt.

"The Garden.- Now let me describe the garden of the Amblyornis. Before the cottage there is a meadow of moss. This is brought to the spot and kept free from grass, stones, or any thing which would offend the eye. On this green turf flowers and fruits of pretty colour are placed so as to form an elegant little garden. The greater part of the decoration is collected round the entrance to the nest; and it would appear that the husband offers there his daily gifts to his wife. The objects are very varions, but always of vivid colour. There were some fruits of a Garcinia like a small-sized apple. Others were the fruits of Gardenias of a deep yellow colour in the interior. I saw also small rosy fruits, probably of a Scitamineous plant, and beautiful rosy flowers of a splendid new Vaccinium (Agapetes amblyornithis). There were also fungi and mottled insects placed on the turf. As soon as the objects are faded they are moved to the back of the hut.

"The good taste of the Amblyornis is not only proved by the nice home it builds. It is a clever bird, called by the inhabitants 'Buruk Gurea' (master bird), since it imitates the songs and screamings of numerous birds so well that it brought my hunters to despair, who were but too often misled by the bird. Another name of the bird is 'Tukan Robon,' which means a gardener."

The general colour of the present species is dark brown, rather more rufous on the head and upper back; the wings also rufous brown, the primaries darker brown; tail dark brown; entire under surface dark buff. The sexes, according to Professor Schlegel, are alike in plumage.

The figures in the Plate represent a pair of birds of the present species, the larger one being a little under life-size. They are drawn from specimens in my own collection. The representation of the garden and cabin is adapted from the woodcut given in the 'Gardeners' Chronicle,' which is, in turn, derived from Dr. Beccari's original illustration. 


\section{$2 \mathrm{BHL}$ Biodiversity Heritage Library}

Gould, John and Sharpe, Richard Bowdler. 1879. "Amblyornis inornata, Gardener Bower-bird [PI. 46]." The birds of New Guinea and the adjacent Papuan islands : including many new species recently discovered in Australia 1(IX), -. https://doi.org/10.5962/p.322645.

View This Item Online: https://www.biodiversitylibrary.org/item/229855

DOI: https://doi.org/10.5962/p.322645

Permalink: https://www.biodiversitylibrary.org/partpdf/322645

\section{Holding Institution}

Smithsonian Libraries

\section{Sponsored by}

Biodiversity Heritage Library

\section{Copyright \& Reuse}

Copyright Status: Public domain. The BHL considers that this work is no longer under copyright protection.

This document was created from content at the Biodiversity Heritage Library, the world's largest open access digital library for biodiversity literature and archives. Visit BHL at https://www.biodiversitylibrary.org. 